\title{
Interactions of long-chain homologues of colchicine with tubulin
}

\author{
Ana Marzo-Mas, ${ }^{a}$ Pascale Barbier, ${ }^{b}$ Gilles Breuzard, ${ }^{b}$ Diane Allegro, ${ }^{b}$ Eva Falomir, ${ }^{a}$ Juan Murga, ${ }^{a} *$ \\ Miguel Carda ${ }^{a}$ Vincent Peyrot, ${ }^{b} *$ and J. Alberto Marco ${ }^{c}$
}

åDepart. de Q. Inorgánica y Orgánica, Univ. Jaume I, E-12071 Castellón, Spain

bAix-Marseille Université, Inserm, CRO2 UMR_S 911, Faculté de Pharmacie, 13385, Marseille, France

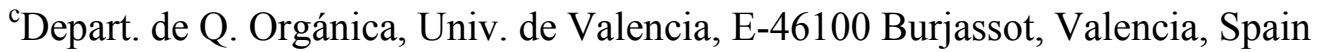

*Authors to whom correspondence should be addressed. E-Mail addresses: jmurga@uji.es, vincent.peyrot@univ-amu.fr.

\begin{abstract}
Several colchicine analogues in which the $\mathrm{N}$-acetyl residue has been replaced by aliphatic, straightchain acyl moieties, have been synthesized. These compounds show high cytotoxic activity at the nanomolar level against the tumoral cell lines HT-29, MCF-7 and A549. Some of them exhibit activities in the picomolar range against the HT-29 line and are thus two to three orders of magnitude more cytotoxic than colchicine. In this specific cell line, the activities were found to be closely related to the length of the acyl carbon chain, an increase in the latter giving rise to an increase in the cytotoxicity with a maximum in the range of 10-12 carbon atoms, followed by a decrease in activity with still longer chains. Some of the compounds inhibit microtubule assembly and induce the formation of abnormal polymers and present in most cases better apparent affinity constants than colchicine. In addition, at $\mathrm{IC}_{50}$ concentrations the analogues block the cell cycle of $\mathrm{A} 549$ cells in the $\mathrm{G} 2 / \mathrm{M}$ phase. Molecular docking studies suggest that, while interactions of the colchicine analogues with the
\end{abstract}


colchicine binding site at $\beta$-tubulin are still present, the increase in the acyl chain length leads to the progressive development of new interactions, not present in colchicine itself, with the neighboring $\alpha$ tubulin subunit. Indeed, sufficiently long acyl chains span the intradimer interface and contact with a hydrophobic groove in $\alpha$-tubulin. It is worth noting that some of the compounds show cytotoxicity at concentrations three orders of magnitude lower than colchicine. Their pharmacological use in cancer therapy could possibly be performed with lower dosages and be thus endowed with less acute toxicity problems than in the case of colchicine.

\section{KEYWORDS}

tubulin, colchicine, microtubules, abnormal polymerization, cytotoxicity, docking studies.

\section{Introduction}

Since life began on Earth, Nature has been producing small-molecule products which can interact inside living organisms with macromolecular targets that contain structural domains similar to human proteins. The result of this natural selection process has been a plethora of structures that developed optimal interactions with many biological targets [1]. Natural product research therefore is a growing domain at the interface of chemistry and biology that continuously generates new chemical entities with high pharmacological interest [2].

During the past few years we have been investigating a range of analogues of natural products [3] for their potential value in anticancer therapy [4]. Research has shown that the onset of cancer may be triggered by a number of both internal and external factors. This has motivated the development of various types of therapeutic treatments [5]. Among these is the use of cytotoxic drugs which often lead to cell apoptosis [6].

Microtubules are dynamic polymers that play a very important role in many cellular processes, particularly in cell division, as they are the key constituents of the mitotic spindle. They are hollow tubes having an external diameter of approximately $25 \mathrm{~nm}$. Microtubules are composed of a heterodimeric protein formed through the non-covalent binding of two monomeric constituents, $\alpha$ - and $\beta$-tubulin [7]. For cell division to occur in the normal way, microtubules must be in a constant state of formation and disruption, a process called microtubule dynamic instability in which GTP hydrolysis into GDP plays an essential role [8].

It is clear that any molecule which interacts with microtubules can influence the cell division process of both normal and tumoral cells. This influence may be exerted by molecules that interact with 
tubulin, which would explain why tubulin-binding molecules (TBM) constitute a very important category of anticancer agents [9]. TBM interfere with microtubule assembly and functions, either by causing disruption of the microtubules or else through their stabilization. Most of the active drugs which have been describe earlier are either natural products or their derivatives [10]. Major drugs can already be found on the market, while many more promising compounds are now in clinical trials [9, 10].

Obviously, discovery and subsequent investigation of new drugs constitute an important activity in chemistry and pharmacology. Our interest in natural product analogues has led us to prepare several structural classes and to investigate their action on the aforementioned types of biological activity. Among the natural products included in our research, colchicine (Fig. 1) is now become of particular interest to us. Colchicine has been successfully employed to treat gout and is also being used for the treatment of familial Mediterranean fever. Unfortunately, the marked toxicity of colchicine has prevented its use in cancer therapy [11]. Very recently, we have published two reports on the cytotoxicity of several colchicine analogues $[4,12]$.

Colchicine inhibits microtubule assembly in vitro through a substoichiometric poisoning mechanism. The compound binds to tubulin at a specific binding site at the $\beta$-subunit proximal to the intradimer interface that separates the latter from the neighbor $\alpha$-subunit. Colchicine forms complexes which then add to the microtubule ends capping them and making further free tubulin dimer addition impossible [13].

\section{Research purpose}

In continuation of our research on novel natural product analogues with potential utility in cancer therapy $[4,12]$ and on the basis of the aforementioned aspects, we wanted to ascertain whether modifications in the $\mathrm{N}$-acyl residue of the colchicine molecule might give rise to noticeable changes in the biological activity. Thus, we have prepared amides 1-10 where the $\mathrm{N}$-acetyl residue of colchicine has been replaced by straight-chain, aliphatic $\mathrm{N}$-acyl moieties bearing up to eighteen carbon atoms in the carbon chain.

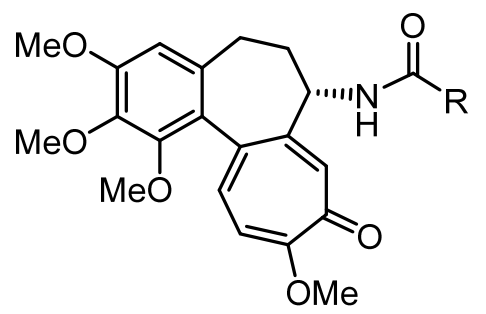

Colchicine $\mathrm{R}=\mathrm{Me}$

$1 \mathrm{R}=\left(\mathrm{CH}_{2}\right)_{2} \mathrm{CH}_{3}$

$6 \mathrm{R}=\left(\mathrm{CH}_{2}\right)_{10} \mathrm{CH}_{3}$

$2 \mathrm{R}=\left(\mathrm{CH}_{2}\right)_{4} \mathrm{CH}_{3} \quad 7 \mathrm{R}=\left(\mathrm{CH}_{2}\right)_{11} \mathrm{CH}_{3}$

$3 \mathrm{R}=\left(\mathrm{CH}_{2}\right)_{6} \mathrm{CH}_{3} \quad 8 \mathrm{R}=\left(\mathrm{CH}_{2}\right)_{12} \mathrm{CH}_{3}$

$4 \mathrm{R}=\left(\mathrm{CH}_{2}\right)_{8} \mathrm{CH}_{3} \quad 9 \mathrm{R}=\left(\mathrm{CH}_{2}\right)_{14} \mathrm{CH}_{3}$

$5 \mathrm{R}=\left(\mathrm{CH}_{2}\right)_{9} \mathrm{CH}_{3} \quad 10 \mathrm{R}=\left(\mathrm{CH}_{2}\right)_{16} \mathrm{CH}_{3}$ 
Figure 1. Structure of colchicine derivatives investigated in this study.

\section{Synthetic work}

$\mathrm{N}$-acyl colchicine derivatives 1-10 were prepared from the trifluoroacetate salt of N-deacetyl colchicine 11 [14] as depicted in Scheme 1. Treatment of 11 with the corresponding carboxylic acid in the presence of DCC and DMAP gave rise to N-acyl derivatives 1-10 with fair to good yields. Details about the precise reaction conditions and yields are indicated in the Experimental Part (graphical spectra and physical, IR, NMR and Mass spectrometry data are provided in the Supporting Information) [15].

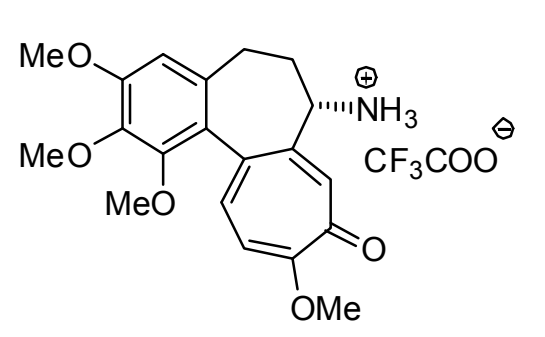

11

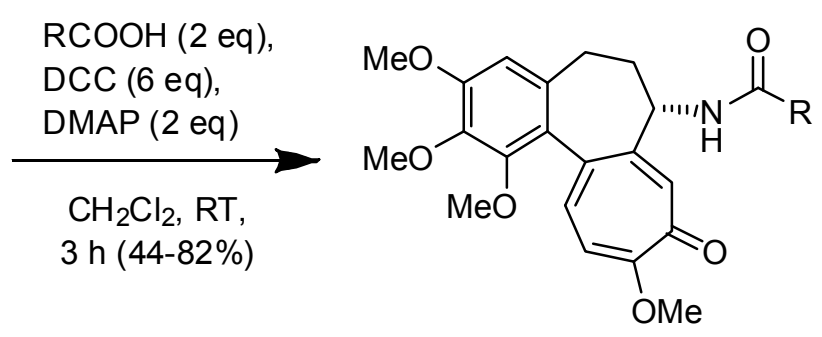

$1-10$

Scheme 1. Synthesis of colchicine derivatives 1-10.

\section{Biological work}

\subsection{Cytotoxic effects}

The cytotoxic ability of compounds 1-10 was established by means of their $\mathrm{IC}_{50}$ values towards the tumoral cell lines HT-29 (human colon adenocarcinoma), MCF-7 (breast adenocarcinoma) as well as towards the non-tumoral cell line HEK-293 (human embryonic kidney cells). Results are presented in Table 1 along with the calculated selectivity indexes $\mathrm{SI}_{\mathrm{A}}$ (for HT-29 cell line) and $\mathrm{SI}_{\mathrm{B}}$ (for MCF-7 cell line), obtained by dividing the $\mathrm{IC}_{50}$ values of the non-tumoral cell line (HEK-293) by those of the corresponding tumoral cell line. The higher the SI index, the higher the therapeutic safety margin.

Table 1. Cytotoxicity of colchicine analogues 1-10 toward tumoral cell lines HT-29 and MCF-7 and one non-tumoral cell line HEK-293. ${ }^{\mathrm{a}}$

\begin{tabular}{|c|c|c|c|c|c|}
\hline Drug & HT-29 & MCF-7 & НЕК-293 & $\mathbf{S I}_{\mathbf{A}}{ }^{\mathbf{b}}$ & $\mathbf{S I}_{\mathbf{B}}{ }^{\mathrm{c}}$ \\
\hline Colchicine & $50 \pm 3$ & $12 \pm 7$ & $5 \pm 1$ & 0.1 & 0.42 \\
\hline 1 & $10 \pm 2$ & $13 \pm 1$ & $13.5 \pm 0.5$ & 1.4 & 1.0 \\
\hline 2 & $3.37 \pm 0.15$ & $7.02 \pm 0.05$ & $7.1 \pm 0.3$ & 2.1 & 1.0 \\
\hline
\end{tabular}




$\begin{array}{llllll}\mathbf{3} & 1.69 \pm 0.09 & 23.0 \pm 0.5 & 18.9 \pm 1.1 & 11.2 & 0.8 \\ \mathbf{4} & 0.143 \pm 0.011 & 29 \pm 4 & 0.242 \pm 0.005 & 1.7 & <0.1 \\ \mathbf{5} & 0.041 \pm 0.004 & 1.77 \pm 0.13 & 0.17 \pm 0.04 & 4.2 & 0.1 \\ \mathbf{6} & 0.27 \pm 0.03 & 0.53 \pm 0.23 & 0.23 \pm 0.06 & 0.9 & 0.4 \\ \mathbf{7} & 7.0 \pm 0.7 & 6.8 \pm 1.7 & 1.5 \pm 0.3 & 0.2 & 0.2 \\ \mathbf{8} & 36.0 \pm 1.0 & 20 \pm 7 & 46 \pm 3 & 1.3 & 2.3 \\ \mathbf{9} & 184 \pm 6 & 720 \pm 60 & 244 \pm 7 & 1.3 & 0.3 \\ \mathbf{1 0} & 1010 \pm 80 & 120 \pm 50 & 766 \pm 10 & 0.8 & 6.4\end{array}$

${ }^{\mathrm{a}} \mathrm{IC}_{50}$ values are expressed as the compound concentration $(\mathrm{nM})$ that inhibits the cell growth by $50 \%$. Data are the average $( \pm \mathrm{SD})$ of three experiments. ${ }^{\mathrm{b}} \mathrm{SI}_{\mathrm{A}}=\mathrm{IC}_{50}(\mathrm{HEK}-293) / \mathrm{IC}_{50}(\mathrm{HT}-29) .{ }^{\mathrm{c}} \mathrm{SI}_{\mathrm{B}}=\mathrm{IC}_{50}(\mathrm{HEK}-293) / \mathrm{IC}_{50}(\mathrm{MCF}-7)$.

The observed $\mathrm{IC}_{50}$ values are in most cases in the medium to low nanomolar range. The results for the HT-29 cell line deserve particular mention, as the lowest IC $_{50}$ values are observed with this cell line. Thus, all compounds except 9 and $\mathbf{1 0}$ showed $\mathrm{IC}_{50}$ values in the low nanomolar range, with 4, 5 and 6 exhibiting very high cytotoxicities situated in the picomolar range, therefore two to three orders of magnitude more cytotoxic than colchicine itself (values highlighted in italics). A clear correlation is observed between the length of the acyl chain and the potency of the compound: the $\mathrm{IC}_{50}$ values decrease with increasing length of the aliphatic chain up to the 11-carbon acyl chain, and then increase again. Indeed, the highest cytotoxicity (lowest $\mathrm{IC}_{50}$ value) is observed in compound $\mathbf{5}$, with an aliphatic acyl chain of 11 carbon atoms. In addition, compound 5 also shows a high selectivity index in the HT29 cell line. The decrease of cytotoxicity for the compounds having the longest acyl chains $(\mathbf{8}-\mathbf{1 0}, \geq 14$ carbon atoms) could be related to an increase in hydrophobicity, the diffusion through the plasmatic membrane of cells becoming more difficult for these compounds. Five compounds (2-6) were thus selected for further biological evaluations. The selection was made on the basis of products showing particularly low $\mathrm{IC}_{50}$ values (high cytotoxicity) in the HT-29 cell line.

\subsection{Tubulin assembly}

Effects on tubulin self-assembly was determined in $20 \mathrm{mM}$ sodium phosphate $(\mathrm{NaPi}), 10 \mathrm{mM}$ $\mathrm{MgCl}_{2}, 1 \mathrm{mM}$ EGTA, 3.4 M glycerol and $0.1 \mathrm{mM} \mathrm{GTP}$ at $\mathrm{pH}=6.5$ in the presence of $10 \mu \mathrm{M}$ of colchicine (as a positive control inhibitor) and $10 \mu \mathrm{M}$ of compounds 2-6. Figure 2 shows the effects on the microtubule formation studied by turbidity time-course measurements. A solution of $15 \mu \mathrm{M}$ of tubulin was incubated at room temperature with $10 \mu \mathrm{M}$ colchicine (CLC hereafter in figures) and compounds 2-6 for $10 \mathrm{~min}$, which is the time necessary to reach the equilibrium state of the binding 
reaction between drugs and tubulin. Subsequently, the microtubule formation was started by increasing the temperature to $37^{\circ} \mathrm{C}$ and absorbance at $400 \mathrm{~nm}$ was followed over time.

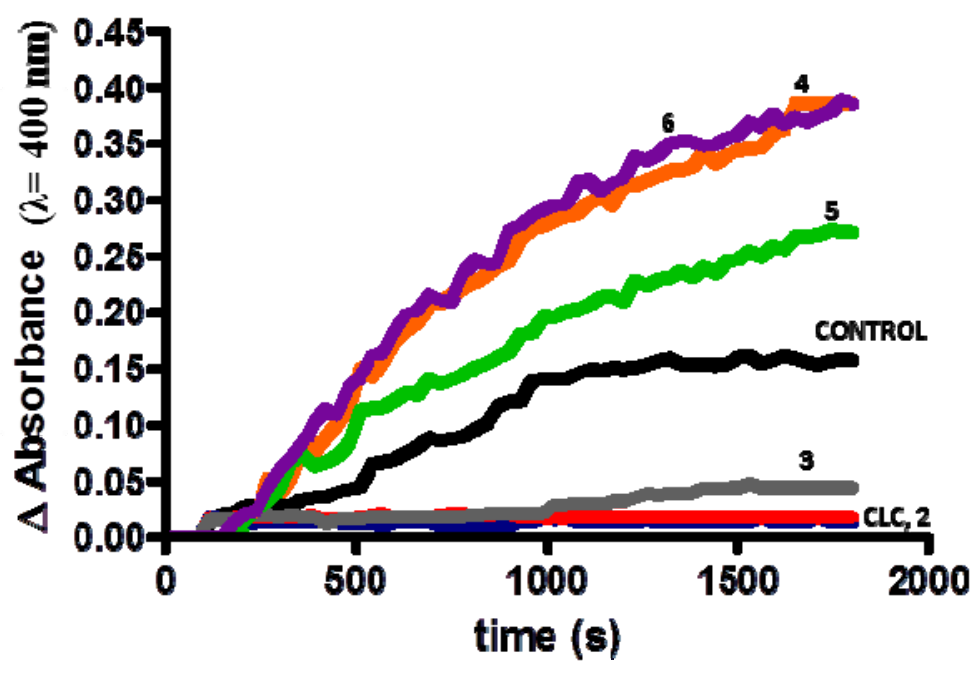

Figure 2. Effects of colchicine and compounds 2-6 on the in vitro tubulin assembly. The lines in the figure show the turbidity time course of polymerization of tubulin alone (black) at $15 \mu \mathrm{M}$, colchicine (blue) at $10 \mu \mathrm{M}, 2$ (red) at $10 \mu \mathrm{M}, 3$ (gray) at $10 \mu \mathrm{M}, 4$ (orange) at $10 \mu \mathrm{M}, 5$ (green) at $10 \mu \mathrm{M}$ and 6 (purple) at $10 \mu \mathrm{M}$.

As structural analogues of colchicine, the compounds under study were expected to inhibit the formation of microtubules. Indeed, and as in the case of colchicine (blue line, overlapped by the red line), compound 2 at $10 \mu \mathrm{M}$ concentration showed a full inhibition of microtubule formation (red line). Compound 3 inhibits around $80 \%$ of the microtubule formation (grey line). Interestingly, an increase in turbidity was observed with compounds 4,5 and $\mathbf{6}$ that could be due to the formation of abnormal polymers. Indeed, formation of the tubulin-colchicine complex is known to induce tubulin conformational changes which result in GTPase activity [16] and polymerization into abnormal polymers [17].

In view of the above results, it was thus necessary to examine the effects of the drugs on tubulin self-assembly at lower concentrations in order to avoid the formation of abnormal polymers of tubulin. Figure 3 displays, as an example, the effect of compound $\mathbf{4}$ on tubulin self-assembly in vitro whereby a clear inhibition was noticed as a function of the concentrations of drug added. It turns out that the rate of assembly and the final amount of microtubules are lower in the presence of substoichiometric concentrations of the compound 4. Indeed, the electron micrographs (see Supplementary Information, 
Figure SI-1) show much less microtubules in the presence of compound 4 at $0.1 \mu \mathrm{M}$ concentration than in the absence of it.
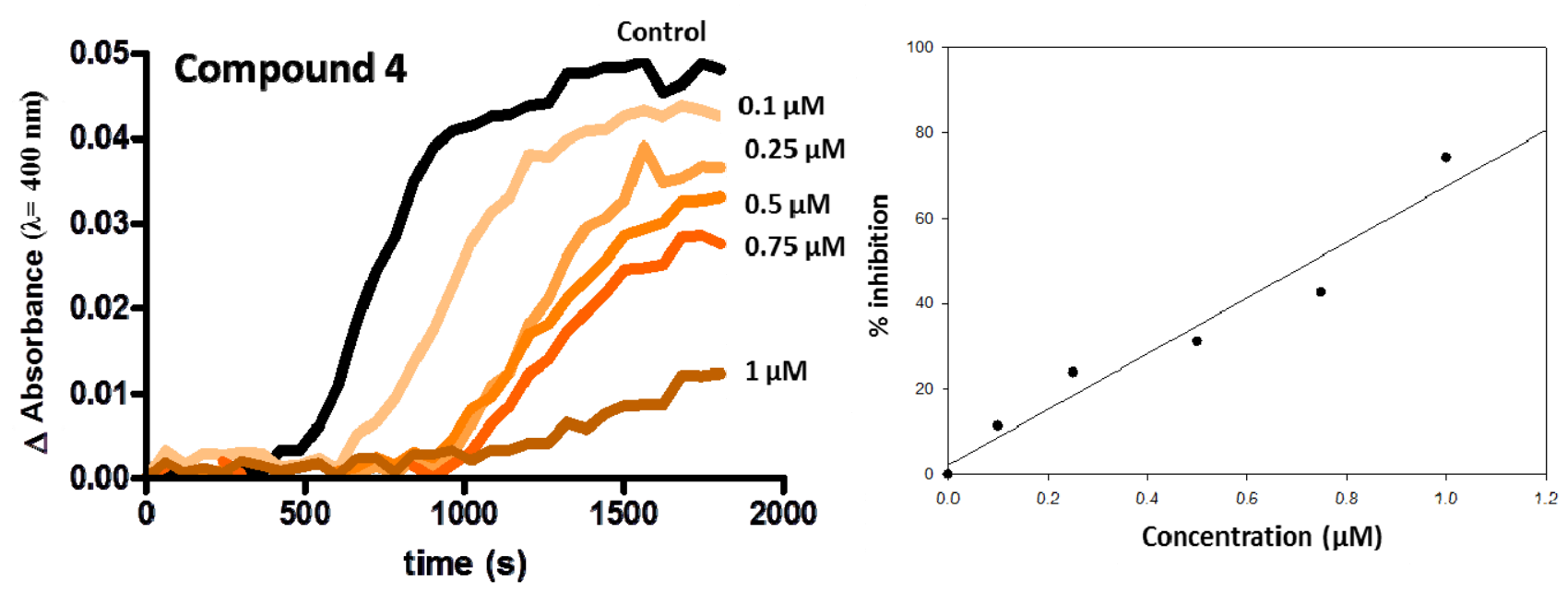

Figure 3. Effect of compound $\mathbf{4}$ on the turbidity time-course of in vitro microtubule formation. The left panel shows tubulin polymerization at $15 \mu \mathrm{M}$ without 4 (control) and in the presence of $0.1,0.25,0.5$, 0.75 and $1 \mu \mathrm{M}$ of compound 4 . The right panel presents the correspondent percentage of inhibition by 4.

The inhibitory effects on microtubule formation of these colchicine analogues (2-6) by means of measuring the $\mathrm{IC}_{50}$ values are reported in Table 2.

Table 2. Inhibitory effects on microtubule assembly at $37^{\circ} \mathrm{C}$ and $15 \mu \mathrm{M}$ of tubulin. ${ }^{\mathrm{a}}$

\begin{tabular}{cl} 
Compound & Tubulin inhibition $\mathbf{I C}_{\mathbf{5 0}}(\boldsymbol{\mu M})$ \\
\hline Colchicine & $1.8 \pm 0.3$ \\
$\mathbf{2}$ & $2.06 \pm 0.20$ \\
$\mathbf{3}$ & $1.08 \pm 0.05$ \\
$\mathbf{4}$ & $0.70 \pm 0.07$ \\
$\mathbf{5}$ & $0.79 \pm 0.06$ \\
$\mathbf{6}$ & $1.21 \pm 0.14$ \\
\hline
\end{tabular}

${ }^{a}$ Data are the average $( \pm \mathrm{SD})$ of three experiments.

Compound 2 showed an inhibitory effect on microtubule assembly similar to colchicine. With compounds 3-6, however, a 50\% of microtubule assembly inhibition was measured at concentrations lower than colchicine, with compound 4 being the most active one. 
Then, it was of interest to examine the ability of the compounds under study to induce the formation of abnormal polymers [18]. This is a characteristic feature of the interaction of colchicine and its analogues with tubulin [19]. Indeed, the 1:1 tubulin-colchicine complex polymerizes into anomalous structures in the absence of glycerol (tubulin alone does not polymerize in these conditions) $[18,20]$. In order to check the formation of such abnormal polymers, a new buffer was used consisting in $20 \mathrm{mM}$ $\mathrm{NaPi}, 16 \mathrm{mM} \mathrm{MgCl}_{2}$ and $0.1 \mathrm{mM} \mathrm{GTP}$ at $\mathrm{pH} 7$ [19]. A solution of $15 \mu \mathrm{M}$ of tubulin and $50 \mu \mathrm{M}$ solutions of colchicine and compounds 2-6 were incubated for $10 \mathrm{~min}$ a room temperature. The polymerization reaction was then started by increasing the temperature to $37^{\circ} \mathrm{C}$. The results of these experiments are shown in Figure 4: large increases in turbidity were observed for all compounds. However, compounds 4-6 were more active than compounds 2 and $\mathbf{3}$. The formation of abnormal polymers with compounds 2-6 was also followed by electron microscopy (see Supplementary Information, Figure SI-2). As expected, we observed the absence of microtubules and the presence of poorly defined filamentous sheet structures for colchicine and for the two studied compounds.

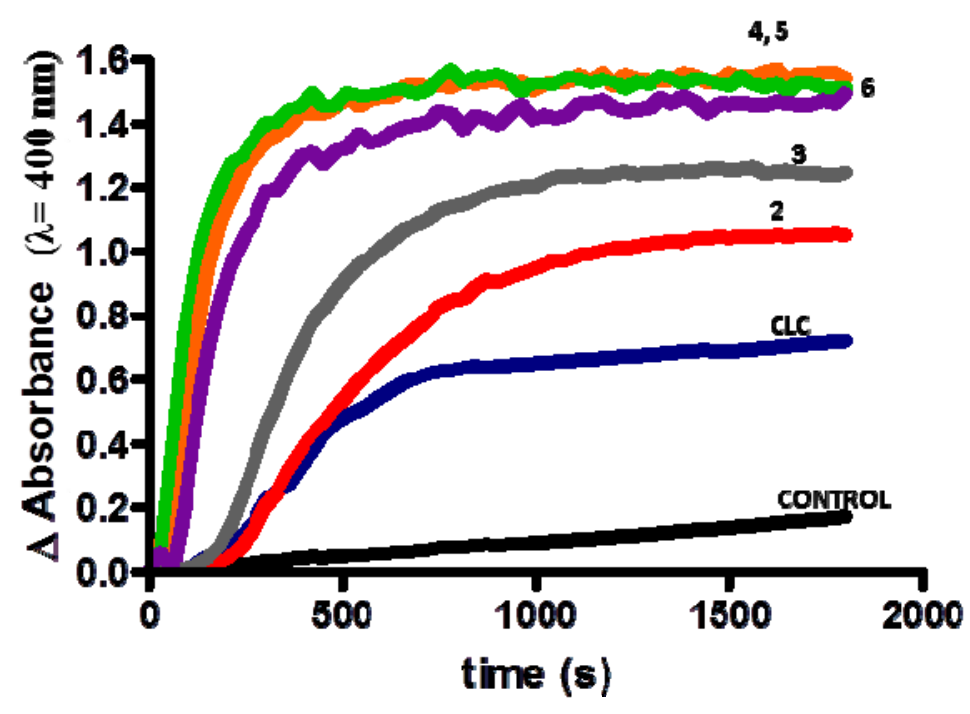

Figure 4. Effect of colchicine and compounds 2-6 on in vitro abnormal polymer formation. The lines in the figure show the effect of tubulin alone (black) at $15 \mu \mathrm{M}$, colchicine (blue) at $50 \mu \mathrm{M}, 2$ (red) at 50 $\mu \mathrm{M}, 3$ (grey) at $50 \mu \mathrm{M}, 4$ (orange) at $50 \mu \mathrm{M}, 5$ (green) at $50 \mu \mathrm{M}$ and 6 (purple) at $50 \mu \mathrm{M}$.

\subsection{Specificity and localization of the interaction}

We decided to determine whether the structural analogues of colchicine were able to bind to tubulin liganded to colchicine. Figure 5 (panel A) shows the time course of fluorescence change induced by the 
association of $10 \mu \mathrm{M}$ of colchicine and $10 \mu \mathrm{M}$ of tubulin at $25^{\circ} \mathrm{C}$ (red trace). The equilibrium of the binding process is reached after 50 minutes. Addition of $20 \mu \mathrm{M}$ of compound 4 to tubulin (black trace) produced a large increase of the fluorescence; furthermore, the equilibrium is reached faster than with colchicine alone (red trace). Colchicine has a very low kinetic rate constant for the dissociation process, so that we used this property to perform the competition experiments. The tubulin-colchicine complex was first formed and then $20 \mu \mathrm{M}$ of $\mathbf{4}$ was added (as it was done with tubulin alone). In Figure 5 (panel B), no large increase of fluorescence signal is observed after the addition of 4 . This indicates that it cannot bind to tubulin. This also indicates that compound $\mathbf{4}$ binds to or near the colchicine site.
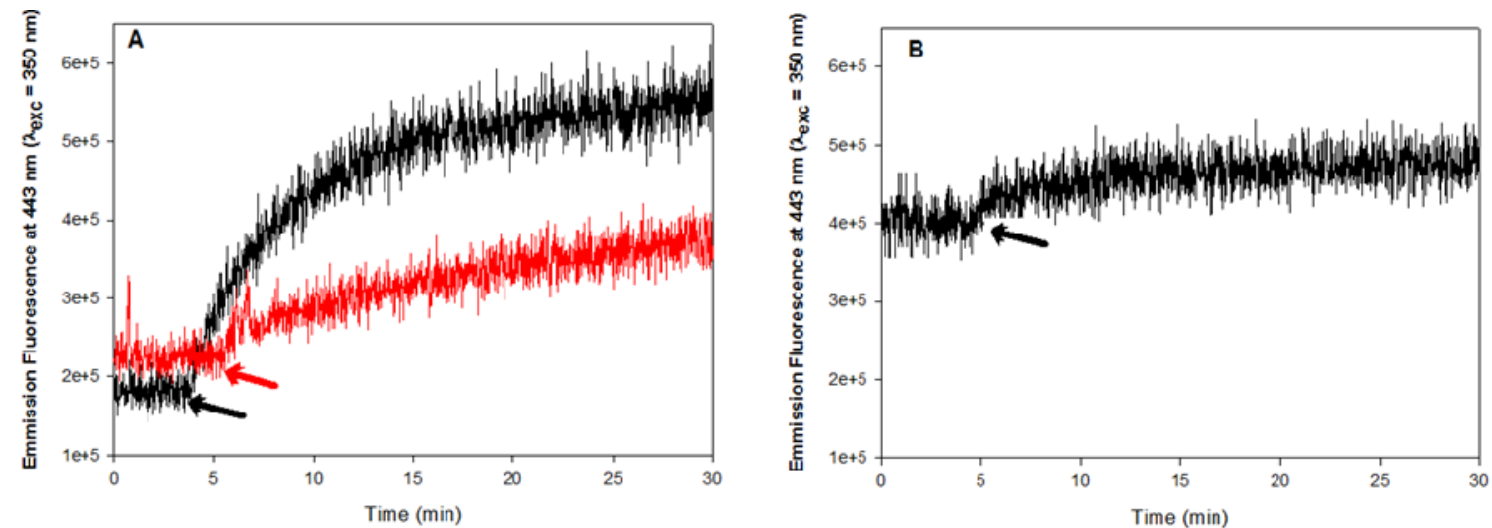

Figure 5. (A) Time course of the fluorescence change upon binding $20 \mu \mathrm{M}$ of compound 4 (black arrow, and black trace) and $10 \mu \mathrm{M}$ of colchicine (red arrow and red trace) to $10 \mu \mathrm{M}$ of tubulin at $25^{\circ} \mathrm{C}$. Arrows indicate the addition of compound 4 and colchicine. (B) Time course of the fluorescence change when $20 \mu \mathrm{M}$ of compound 4 is added to $10 \mu \mathrm{M}$ tubulin-colchicine complex. The black arrow indicates the addition of compound 4 . The observed increase in fluorescence was not the same as that observed in the absence of colchicine. This indicates that $\mathbf{4}$ competes with the natural product for the same binding site.

The poor amplitude of the residual signal obtained is probably the consequence of a weak displacement of colchicine by the compound and association of the latter with free tubulin. This competition experiment indicates that compounds bind to tubulin at a site involving the colchicine site.

\subsection{Interaction with tubulin: binding parameters}

The binding of colchicine analogues implicated tryptophan residues and quenched the intrinsic tubulin fluorescence. The intrinsic fluorescence emission spectra of tubulin was obtained by exciting the tryptophan residues at $295 \mathrm{~nm}$. Then, examination of the fluorescence of tubulin in presence of 4 
revealed a decrease in the intrinsic protein fluorescence signal. The measurements were performed after 15 minutes, which is the time required to ensure that the equilibrium state of the binding reaction between tubulin and the ligands has been reached. As an example, Figure 6 shows the results observed for the specific case of 4 . A decrease in the fluorescence emission intensity at $330 \mathrm{~nm}$ was observed with an increase of the concentrations of 4 . This quenching of fluorescence was used to carry out binding titration experiments. The results are indicated in the graph inserted in Figure 6, which shows the titration curve for the association of $\mathbf{4}$ to tubulin. Similar results are obtained for the other compounds and for colchicine [18]. Quenching of tubulin fluorescence suggests that compounds 2-6 bind to tubulin close to a fluorophoric residue, i.e., tryptophan.

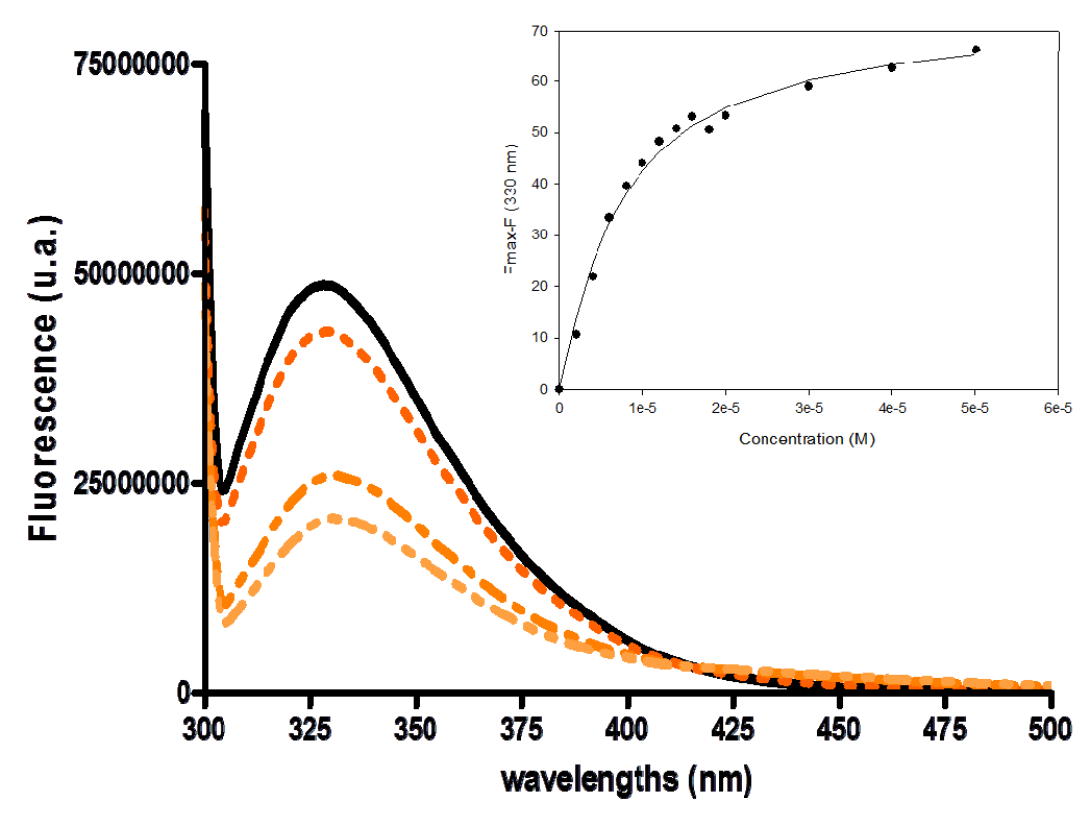

Figure 6. Tryptophan fluorescence modifications of tubulin upon binding of compound 4 at $25^{\circ} \mathrm{C}$ in PG buffer, pH 7. The excitation wavelength was $295 \mathrm{~nm}$. Fluorescence emission of $2 \mu \mathrm{M}$ tubulin alone (black line), with $2 \mu \mathrm{M}(\cdots), 10 \mu \mathrm{M}(-\cdot)$ and $20 \mu \mathrm{M}(-\cdots)$ of 4 . The inset shows the quenching fluorescence titration curve inverted produced by 4 binding to $2 \mu \mathrm{M}$ of tubulin; the solid line is the fitting curve obtained as described in the Experimental Part.

The apparent affinity stoichiometric constants $\left(\mathrm{K}_{\mathrm{a}}\right)$ were then calculated for colchicine and for compounds 2-6 (Table 3) [21]. 
Table 3. Binding Parameters of Colchicine and Compounds 2-6 to tubulin in PG buffer at $25^{\circ} \mathrm{C}^{\mathrm{a}}$.

\begin{tabular}{cc} 
Compound & $\begin{array}{c}\text { Equilibrium binding constant } \\
\text { to tubulin } \mathbf{K}_{\mathbf{a}} \mathbf{x} \mathbf{1 0}^{\mathbf{4}}\left[\mathbf{M}^{\mathbf{- 1}}\right]\end{array}$ \\
\hline Colchicine & $9 \pm 3$ \\
$\mathbf{2}$ & $6.4 \pm 2.0$ \\
$\mathbf{3}$ & $5.2 \pm 1.1$ \\
$\mathbf{4}$ & $17.9 \pm 2.3$ \\
$\mathbf{5}$ & $18.4 \pm 1.6$ \\
$\mathbf{6}$ & $19 \pm 2.3$ \\
\hline
\end{tabular}

${ }^{a}$ Data are the average $( \pm \mathrm{SD})$ of three experiments.

Colchicine analogues $\mathbf{2}$ and $\mathbf{3}$ have apparent affinity constants slightly lower than colchicine. In contrast, compounds 4, 5 and 6 present higher apparent affinity binding constants than the natural alkaloid. These molecules were able to induce the formation of abnormal polymers at lower concentrations values than colchicine. These apparent binding constant values were close to that of the colchicine analogue MTC [22].

\subsection{Mitotic arrest and inhibition of interphase microtubules of cultured cells}

Further in vitro and in-cell studies have been done in order to establish a relationship between the lengths of the acyl chain and the biological activity of compounds 2-6, which showed the highest cytotoxicities towards the HT-29 cell line. Thus, $\mathrm{IC}_{50}$ values were also measured on the A549 tumoral cell line (adenocarcinome human alveolar basal epithelial cells), after $72 \mathrm{~h}$ of incubation (see Table 4, which also includes the calculated selectivity indexes $\mathrm{SI}_{\mathrm{C}}$ ).

Table 4. Cytotoxicity of colchicine analogues 2-6 towards the tumoral cell line A549a .

\begin{tabular}{cll} 
Compound & $\mathbf{A - 5 4 9}$ & $\mathbf{S I}_{\mathbf{C}}^{\mathbf{b}}$ \\
\hline Colchicine & $14 \pm 6$ & 0.36 \\
$\mathbf{2}$ & $18 \pm 2$ & 0.39 \\
$\mathbf{3}$ & $133 \pm 23$ & 0.14 \\
$\mathbf{4}$ & $25 \pm 4$ & $<0.1$ \\
$\mathbf{5}$ & $62 \pm 4$ & $<0.1$ \\
$\mathbf{6}$ & $71.9 \pm 0.8$ & $<0.1$
\end{tabular}

${ }^{\mathrm{a}} \mathrm{IC}_{50}$ values are expressed as the drug concentration $(\mathrm{nM})$ that inhibits the cell growth by $50 \%$. Data are the average $( \pm \mathrm{SD})$ of three experiments. ${ }^{\mathrm{b}} \mathrm{SI}_{\mathrm{C}}=\mathrm{IC}_{50}(\mathrm{HEK}-293) / \mathrm{IC}_{50}(\mathrm{~A} 549)$. 
Most of the $\mathrm{IC}_{50}$ values are in the low nanomolar range although the selectivity indexes $\mathrm{SI}_{\mathrm{C}}$ are in all but one compound lower than colchicine. These $\mathrm{SI}_{\mathrm{C}}$ values slightly diverge from the $\mathrm{SI}_{\mathrm{A}}$ values of the HT-29 line, in which SI values are higher than those of colchicine. Since our colchicine derivatives bind to tubulin and inhibit in vitro microtubule assembly, it was convenient to establish whether they also could inhibit microtubule assembly in living cells and to characterize their effects on microtubules, mitoses and DNA content. Accordingly, subsequent biological studies were carried out using flow cytometry to investigate whether the $\mathrm{IC}_{50}$ concentrations of the compounds could induce a $\mathrm{G} 2 / \mathrm{M}$ block after a $24 \mathrm{~h}$ treatment. Thus, an indirect immunofluorescent assay on the A549 cells line was realized to observe the effect on microtubules during the interphase.

In order to establish the cell cycle distribution, A549 cells were treated for 24 hours with colchicine and compounds 2-6 at $\mathrm{IC}_{50}$ values. The observed results show that all compounds are able to arrest the cell cycle at the G2/M phase, as expected for colchicine derivatives [4,23]. Among all compounds, 5 showed the highest capacity to arrest the cell cycle at its $\mathrm{IC}_{50}$ concentration value (see Figure SI-3 in the Supplementary Information).

Since compounds $\mathbf{2}$ and $\mathbf{4}$ displayed cytotoxicity values similar to that of colchicine in the A549 line, they were selected to perform the immunofluorescence assays. The results are displayed in Figure 7. Colchicine (panel B), compound 2 (panel C) and compound 4 (panel D) are able to completely depolymerize cellular microtubules at $100 \mathrm{nM}$ after 4 hours of treatment.
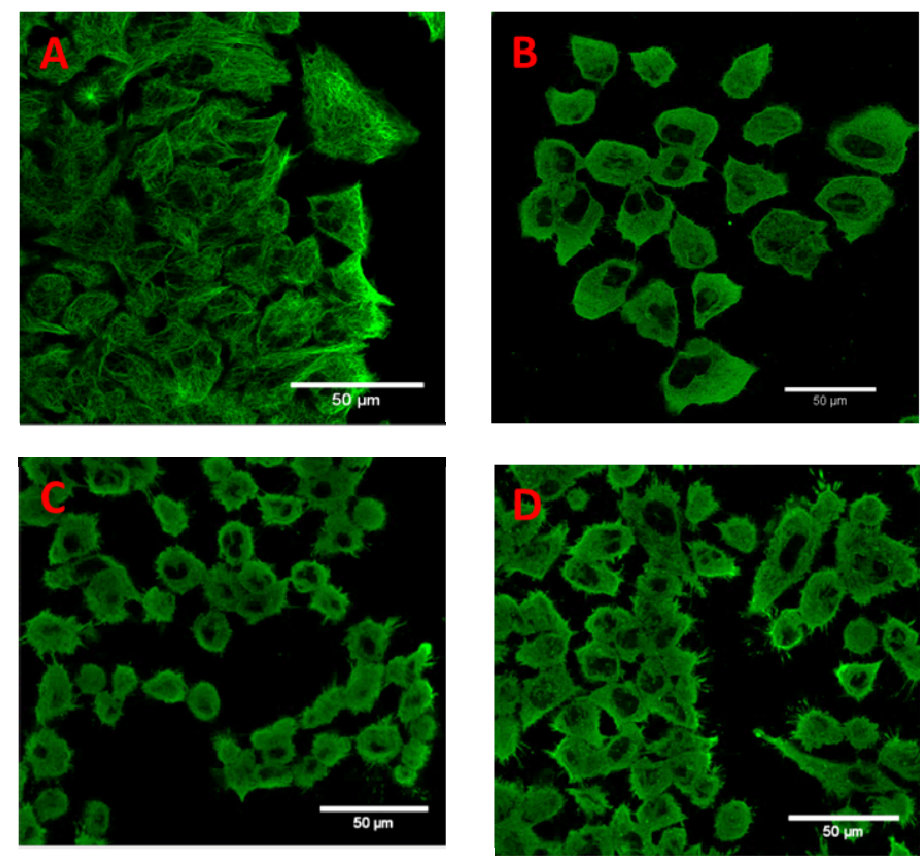
Figure 7. Effects of compounds $\mathbf{2}$ and $\mathbf{4}$ as compared to colchicine on the microtubule network. A549 cells were treated for 4 hours and processed for immunofluorescence microscopy: (A) microtubules of cells without inhibitor, (B) $100 \mathrm{nM}$ colchicine, (C) $100 \mathrm{nM}$ compound 2 and (D) $100 \mathrm{nM}$ compound 4. Microtubules were stained with $\alpha$-tubulin antibodies. The scale bar represents $50 \mu \mathrm{m}$.

\subsection{Molecular docking}

After having demonstrated that synthetic compounds bind to tubulin at/or near the colchicine binding site, and with the aim at gaining insight about the binding site of these colchicine derivatives on tubulin dimers, molecular docking was performed using Autodock 4.2. The crystal structure of $\alpha \beta$ tubulin (PDB ID 1SA0) was used as a template [24]. Figure 8 (A and B panels) shows a superimposition of colchicine (two-carbon acyl chain), $\mathbf{4}$ (ten-carbon acyl chain), $\mathbf{5}$ (eleven-carbon acyl chain), and 6 (twelve-carbon acyl chain) over the structure of DAMA-colchicine [ $N$-deacetyl- $N$-(2mercaptoacetyl)colchicine], obtained from the PDB ID 1SA0 [25].

These docking experiments suggest that these derivatives exhibit conformations very close to that of DAMA-colchicine. Furthermore, the calculations suggest that, while the binding site of the colchicine fragment is situated, as expected, at the $\beta$-tubulin domain, the aliphatic chain spans the intradimer interface zone that separates the $\alpha$ and $\beta$ subunits and inserts itself in a hydrophobic groove located in the $\alpha$-tubulin domain. This is more clearly shown in Figure 8, which contains docking structures of colchicine, 4, 5 and 6 complexed with tubulin (C-F panels). As commented above, the colchicine moiety of these derivatives is located in the colchicine binding site at $\beta$-tubulin, represented in green color in the images. However, the $N$-acyl residue points to a groove in the $\alpha$-tubulin domain (yellow). Sufficiently long aliphatic chains (e.g. 4, 5 or 6) fit well into a hydrophobic groove in $\alpha$-tubulin, and develop more hydrogen bonding interactions than DAMA-colchicine itself (see 2D interactions in Figure SI-4 in Supplementary Information). However, shorter aliphatic chains, as in colchicine itself, are unable to reach this $\alpha$-tubulin groove. Among these three ligands, compound $\mathbf{6}$ is able to insert its aliphatic chain into the aforementioned groove more deeply than the others. This is underscored by an increased number of hydrogen bonding interactions (see Figure SI-4 in Supplementary Information). We have also calculated for colchicine and compounds 2-6 the Gibbs free energies from the docking binding parameters and from the apparent affinity constants, experimentally obtained. These values show the same trend (see Graphic SI-1 in the Supplementary Information). Thus, it can be concluded that the greater in vitro activity of compounds 4-6 on tubulin could be due to the new interactions that they develop with $\alpha$-tubulin. 

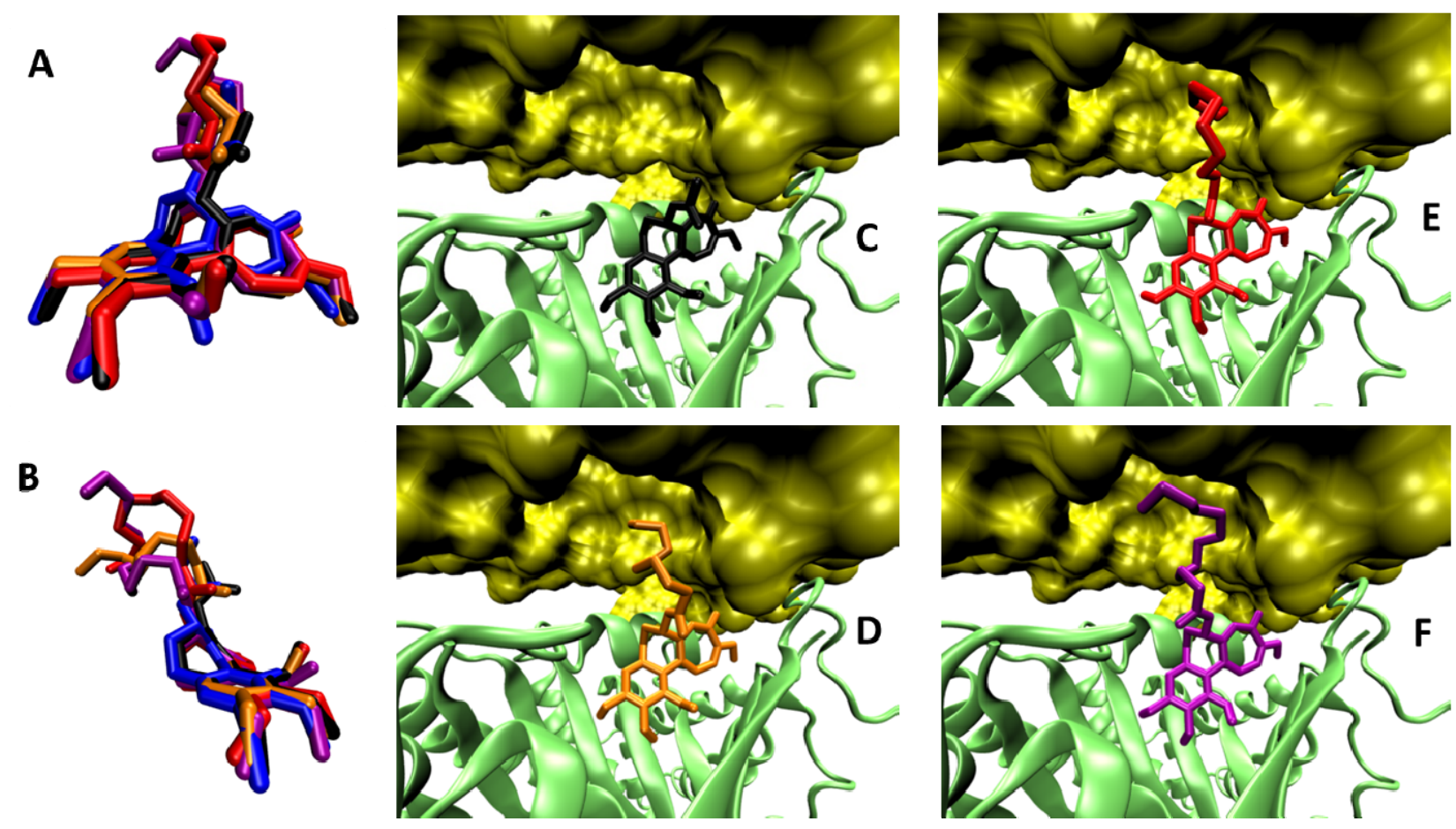

Figure 8. Superimposition of the structures of colchicine (black), 4 (orange), 5 (red) and 6 (purple) on the co-crystallized DAMA-colchicine (blue) at the colchicine binding site. Images A and B correspond to the same superimpositions observed from two different angles. Structures of colchicine (C), 4 (D), 5 (E) and $\mathbf{6}(\mathrm{F})$ at the colchicine binding site. The $\alpha$ - and $\beta$-tubulin subunits are coloured in yellow and green, respectively.

\section{Summary and conclusions}

Colchicine analogues in which the $N$-acetyl residue has been replaced by aliphatic, straight-chain acyl moieties show cytotoxic activities in the medium to low nanomolar range. Of the tested compounds, those with $N$-acyl residues of 10-12 carbon atom length (compounds 4, 5 and $\mathbf{6}$ ) show particularly high cytotoxicities (picomolar range) towards the HT-29 cell line and form abnormal tubulin polymers. This contrasts with the behaviour observed with colchicine, which gives rise to inhibition of tubulin polymerization. By means of competition experiments we have shown that all the studied derivatives bind to tubulin at/or near the colchicine binding site. Compounds $\mathbf{2}$ and $\mathbf{3}$, having the shorter acyl chains, bind to tubulin with similar affinity constants than colchicine, whereas compounds 4,5 and 6 having longer acyl chains bind to tubulin with a higher affinity than colchicine. By means of immunofluorescence experiments on A549 cells, we have shown that the 
compounds inhibit the formation of microtubules at concentrations and incubation times identical to those of colchicine. Moreover, all the studied derivatives cause an extensive arrest of the cell cycle in the $\mathrm{G} 2 / \mathrm{M}$ phase at concentrations corresponding to the $\mathrm{IC}_{50}$ values. For the sake of comparison, compound 5 and colchicine are able to arrest $41 \%$ and $8 \%$, respectively, of the cells in the G2/M phase at such a concentration. It is worth noting that docking calculations have shown that while the binding site of the colchicine fragment is situated, as expected, at the $\beta$-tubulin domain, near the intradimer interface zone that separates the $\alpha$ and $\beta$ subunits, the aliphatic chain of sufficiently long acyl residues (compounds 4-6) spans this interface zone and inserts in a hydrophobic groove located in the $\alpha$-tubulin domain. In addition, 2D representations of compounds 4-6 show more interactions than DAMA-colchicine with the $\alpha$-subunit of tubulin. This may explain the differences in behavior between colchicine and its long-chain homologues. A most interesting aspect of this research is the fact that compounds such as 4-6 show cytotoxicity at concentrations three orders of magnitude lower than colchicine. Their pharmacological use in cancer therapy could possibly be performed with lower dosages and be thus endowed with less acute toxicity problems than in the case of colchicine. Nevertheless, widely in vivo studies should be carried out in order to assess the toxicity of these compounds.

\section{Experimental}

\subsection{Chemistry}

\subsubsection{General procedures}

NMR spectra were measured at $25^{\circ} \mathrm{C}$. The signals of the deuterated solvent $\left(\mathrm{CDCl}_{3}\right)$ was taken as the reference. Multiplicity assignments of ${ }^{13} \mathrm{C}$ signals were made by means of the DEPT pulse sequence. Complete signal assignments in ${ }^{1} \mathrm{H}$ and ${ }^{13} \mathrm{C}$ NMR spectra were made with the aid of $2 \mathrm{D}$ homo- and heteronuclear pulse sequences (COSY, HSQC, HMBC). High resolution mass spectra were run by the electrospray mode (ESMS). IR data were measured with oily films on $\mathrm{NaCl}$ plates (oils) and are given only for relevant functional groups $(\mathrm{C}=\mathrm{O}, \mathrm{NH})$. Optical rotations were measured at $25^{\circ} \mathrm{C}$. Experiments which required an inert atmosphere were carried out under dry $\mathrm{N}_{2}$ in flame-dried glassware. THF was freshly distilled from sodium/benzophenone ketyl and transferred via syringe. Commercially available reagents were used as received. Where solutions were filtered through a Celite pad, the pad was additionally washed with the same solvent used, and the washings incorporated to the main organic layer. 


\subsubsection{General procedure to prepare colchicine analogues 1-10.}

Compound 11 (283 mg, $0.6 \mathrm{mmol})$ and the appropriate acid (1.2 mmol) were dissolved under $\mathrm{N}_{2}$ in dry $\mathrm{CH}_{2} \mathrm{Cl}_{2}(60 \mathrm{~mL})$ and treated with $\mathrm{N}, \mathrm{N}^{\prime}$-dicyclohexylcarbodiimide $(743 \mathrm{mg}, 3.6 \mathrm{mmol})$ and 4-(N,Ndimethylamino)pyridine (147 $\mathrm{mg}, 1.2 \mathrm{mmol}$ ). The mixture was stirred for $3 \mathrm{~h}$ at room temperature and then filtered through Celite. The filtrate was evaporated under reduced pressure, and the residue was subjected to column chromatography on silica gel (EtOAc-acetone, 8:1) to afford the desired compound 1-10. The physical and spectral data are indicated in the Supplementary Information.

Yields: 1, 44\%; 2, 51\%; 3, 82\%; 4, 44\%; 5, 44\%; 6, 61\%; 7, 44\%; 8, 72\%; 9, 46\%; 10, 77\%.

\subsection{Biological studies. Materials and methods}

\subsubsection{Cell culture}

Cell culture media were purchased from Gibco (Grand Island, NY). Fetal bovine serum (FBS) was a product of Harlan-Seralab (Belton, U.K.). Supplements and other chemicals not listed in this section were obtained from Sigma Chemical Co. (St. Louis, MO). Plastics for cell culture were supplied by Thermo Scientific BioLite. All tested compounds were dissolved in DMSO at a concentration of 10 $\mu \mathrm{g} / \mathrm{mL}$ and stored at $-20^{\circ} \mathrm{C}$ until use.

HT-29, MCF-7 and HEK-293 cell lines were maintained in Dulbecco's modified Eagle's medium (DMEM) containing glucose $(1 \mathrm{~g} / \mathrm{L})$, glutamine $(2 \mathrm{mM})$, penicillin $(50 \mathrm{IU} / \mathrm{mL})$, streptomycin $(50$ $\mu \mathrm{g} / \mathrm{mL})$, and amphotericin B $(1.25 \mu \mathrm{g} / \mathrm{mL})$, supplemented with $10 \%$ FBS.

Cells from human non-small lung carcinoma (clone A549; ATCC $n^{\circ}$ : CCL2, MD, USA) were routinely grown at $37^{\circ} \mathrm{C}$ in a humidified atmosphere of $5 \% \mathrm{CO}_{2}$. Cells were maintained in a standard medium composed of RPMI 1640 (Lonza, France) supplemented with 10\% fetal bovine serum (FBS), 2 $\mathrm{mM}$ L-glutamine and 1\% penicillin and streptomycin (Invitrogen). Cells were free from mycoplasma as determined by mycoalert tests (Lonza).

\subsubsection{Cytotoxicity assays}

For cell viability assay on the cell line A549, cells harvested from sub-confluent monolayers were seeded at $25,000 / \mathrm{mL}$ in 96-well microtiter plate (Cambridge Technology, France) and cultured 24 hours under standard conditions. Standard medium was then replaced by fresh medium containing no drugs (control or " 0 ") or compounds at different concentrations. The surviving cells were quantified after $72 \mathrm{~h}$ by the MTT assay, according to the manufacturer's instructions. Briefly, $20 \mu \mathrm{L}$ of 3-(4,5dimethylthiazol-2-yl)-2,5-diphenyltetrazolium bromide (MTT) solution at $5 \mathrm{mg} \cdot \mathrm{mL}^{-1}$ were added to 
cells for $2 \mathrm{~h}$ at $37^{\circ} \mathrm{C}$. The supernatant was discarded and replaced by $200 \mu \mathrm{L}$ of DMSO to dissolve formazan crystals. The absorbance was then read at $540 \mathrm{~nm}$ by spectrophotometry. For all concentrations of compound, cell viability was expressed as the percentage of the ratio between the mean absorbance of treated cells and the mean absorbance of untreated cells. Three independent experiments were performed, and the $\mathrm{IC}_{50}$ values (i.e., concentration half inhibiting cell proliferation) were graphically determined.

A total of $5 \times 10^{3}$ HT-29, MCF-7, or HEK-293 cells in a total volume of $100 \mu \mathrm{L}$ of their respective growth media were incubated with serial dilutions of the tested compounds. The 3-(4,5dimethylthiazol-2-yl)-2,5-diphenyltetrazolium bromide (MTT; Sigma Chemical Co.) dye reduction assay in 96-well microplates was used, as previously described [26]. After 3 days of incubation $\left(37^{\circ} \mathrm{C}\right.$, $5 \% \mathrm{CO}_{2}$ in a humid atmosphere), $10 \mu \mathrm{L}$ of MTT ( $5 \mathrm{mg} / \mathrm{mL}$ in phosphate-buffered saline, PBS) was added to each well, and the plate was incubated for a further $4 \mathrm{~h}\left(37^{\circ} \mathrm{C}\right)$. The resulting formazan was dissolved in $150 \mu \mathrm{L}$ of $0.04 \mathrm{~N} \mathrm{HCl} / 2$-propanol and read at $550 \mathrm{~nm}$. All determinations were carried out in triplicate.

\subsubsection{Fluorescence microscopy}

For immunofluorescence microscopy of the microtubule network, $10^{6}$ cells were plated on coverglass and incubated with the different drugs. Cells were then fixed in 3.7\% formaldehyde (in PBS $\mathrm{pH}$ 7.4) for $20 \mathrm{~min}$ at room temperature, permeabilized with PBS-Triton X-100 0.5\% for $10 \mathrm{~min}$ at room temperature. Direct immunostaining was carried out for $2 \mathrm{~h}$ at room temperature with a primary FITC-conjugated anti- $\alpha$-tubulin antibody (dilution 1:400 in PBS-BSA 1\% from a $1 \mathrm{mg} / \mathrm{mL}$ solution; monoclonal antibody, clone DM1A, Sigma-Aldrich, France). Next, cells were incubated for 45 min at room temperature in darkness with secondary Alexa fluor 488-conjugated antibodies (dilution 1:200 each from $1.5 \mathrm{mg} / \mathrm{mL}$; Molecular Probe, France). Then, cells were washed in PBS and coverglasses were mounted with a drop of ProLong ${ }^{\circledR}$ anti-fade solution (Invitrogen). The cytoskeleton was imaged by a confocal laser scanning microscope (CLSM) Leica SP5 with a Leica inverted microscope, equipped with a Plan-Apochromat $63 \times$ oil immersion objective $(\mathrm{NA}=1.4)$. Each image was recorded with the CLSM's spectral mode selecting specific domains of the emission spectrum. The FITC fluorophore was excited at $488 \mathrm{~nm}$ with an argon laser and its fluorescence emission was collected between $496 \mathrm{~nm}$ and $535 \mathrm{~nm}$. The public-domain ImageJ software was used for image analysis [27]. 


\subsubsection{Cell cycle analysis and mitosis index}

For flow cytometric analysis of DNA content, $4 \times 10^{5}$ cells in exponential growth were treated with the $\mathrm{IC}_{50}$ value and ten times this value of each compound, so $14 \mathrm{nM}$ and $140 \mathrm{nM}$ for CLC, $18 \mathrm{nM}$ and $180 \mathrm{nM}$ compound 2, $133 \mathrm{nM}$ and $1.33 \mu \mathrm{M}$ compound $3,25 \mathrm{nM}$ and $250 \mathrm{nM}$ compound 4, $62 \mathrm{nM}$ and $620 \mathrm{nM}$ compound 5 and $72 \mathrm{nM}$ and $720 \mathrm{nM}$ compound 6 for $24 \mathrm{~h}$ for $24 \mathrm{~h}$. The supernatant and trypsinated cells were harvested then centrifuged $\left(1200 \mathrm{rpm}, 5 \mathrm{~min}, 4^{\circ} \mathrm{C}\right)$. The cell pellet was resuspended in $1 \mathrm{~mL}$ of cold $70 \%$ ethanol for $30 \mathrm{~min}$ at $-20^{\circ} \mathrm{C}$. Cells were centrifuged $(2000 \mathrm{rpm}, 5 \mathrm{~min}$, $4^{\circ} \mathrm{C}$ ) to remove ethanol then the cell pellet was re-suspended in the staining mix containing $50 \mu \mathrm{g} / \mathrm{mL}$ propidium iodide (Molecular Probes, France) and $100 \mu \mathrm{g} / \mathrm{mL}$ RNAse A (Sigma, France) in PBS for 20 min at room-temperature in darkness. Samples were analyzed on a Becton Dickinson FACScan flow cytometer using the CellQuest software, which was also used to determine the percentage of cells in the $\mathrm{G} 2 / \mathrm{M}$ phases of the cell cycle. PI was excited at $488 \mathrm{~nm}$ and fluorescence analyzed at $620 \mathrm{~nm}$ on channel Fl-2.

\subsubsection{Tubulin purification, microtubule assembly and formation of abnormal polymers}

Lamb brain tubulin was purified from brain soluble extracts by a modified Weisenberg procedure consisting in ammonium sulfate fractionation and ion-exchange chromatography $[22,28]$. Pure protein was stored in liquid nitrogen and prepared as described for used [29]. Protein concentrations were determined spectrophotometrically at $275 \mathrm{~nm}$ with a Perkin-Elmer spectrophotometer Lambda 800 with an extinction coefficient of $1.07 \mathrm{~L} . \mathrm{g}^{-1} . \mathrm{cm}^{-1}$ in $0.5 \%$ SDS in neutral aqueous buffer or with an extinction coefficient of $1.09 \mathrm{~L} \cdot \mathrm{g}^{-1} \cdot \mathrm{cm}^{-1}$ in $6 \mathrm{M}$ guanidine hydrochloride.

Microtubule assembly was performed in $20 \mathrm{mM}$ sodium phosphate buffer, $1 \mathrm{mM}$ EGTA, $10 \mathrm{mM}$ $\mathrm{MgCl}_{2}, 3.4 \mathrm{M}$ glycerol and $0.1 \mathrm{mM}$ GTP (pH 6.5 adjusted). The reaction was started by warming the samples at $37^{\circ} \mathrm{C}$ and the mass of polymer was monitored by turbidimetry with a spectrophotometer Beckman DU 7400 at $400 \mathrm{~nm}$ in order to minimize light absorption by compounds. Samples containing compounds and their controls had less than $2 \%$ residual DMSO. For the $\mathrm{IC}_{50}$ determation turbidimetry was measured at $400 \mathrm{~nm}$ with a POLARstar BMG Labtech spectrophotomether using a 96-well plate. Samples containing the compounds and control had less than $1 \%$ residual DMSO. Three independent experiments were done in each case.

Formation of abnormal polymers induced by CLC and compounds 1-10 in $20 \mathrm{mM}$ sodium phosphate buffer, $16 \mathrm{mM} \mathrm{MgCl}_{2}, 0.1 \mathrm{mM} \mathrm{GTP}(\mathrm{pH} 7)$ at $37^{\circ} \mathrm{C}$ was monitored by turbidimetry at 400 $\mathrm{nm}$ in order to minimize light absorption by the compounds. Tubulin was mixed with saturating 
concentration of compounds 1-10 in thermostated cuvettes. The residual quantity of DMSO was less than $2 \%$.

\subsubsection{Transmission electron microscopy}

For standard negative staining, aliquots of $3 \mu \mathrm{L}$ of the protein samples were absorbed onto 200 mesh Formvar carbon-coated copper grid (Canemco Imc. \& Marivac Inc., Lakefield, QC, Canada) negatively stained with $2 \%$ (w/v) uranyl acetate. Grids were observed onto a JEOL (Tokyo, Japan) JEM-1400 transmission electron microscope operated at $80 \mathrm{kV}$.

\subsubsection{Binding measurement by fluorimetric titration}

Fluorescence emission was reported at $330 \mathrm{~nm}$ with the fluorescence spectrophotometer Horiba Jobin Yvon Fluoromax-3. Fluorescence measurements were performed with an excitation wavelength of $295 \mathrm{~nm}$ in order to excitate the tubulin tryptophan residues. PG buffer ( $\mathrm{pH}$ 7) was used to obtain the uncorrected fluorescence spectra using $0.2 \mathrm{~cm}$ (excitation direction) x $1 \mathrm{~cm}$ cells (Hellma) thermostated at $25^{\circ} \mathrm{C}$ by an external water bath. Tubulin $(1-3 \mu \mathrm{M})$ was titrated with the corresponding compound.

The inner filter effect was presented in all compounds and was corrected according to the following equation [30].

$$
F_{\text {oorr }}^{\prime}=F_{\text {obs }}^{\prime} 10^{\left.\delta\left(A_{\text {exp }}+A_{\mathrm{em}}\right) / 2\right]}
$$

$F_{\text {corr }}$ and $F_{\text {obs }}$ are the corrected and observed fluorescence values at the emission wavelengths. $A_{\text {exc }}$ and $\mathrm{A}_{\mathrm{em}}$ are the absorptions at the excitation and emission wavelengths, calculated with the formula $A_{x}=\varepsilon_{x} l_{x} C$, where $\mathrm{x}$ is the excitation or emission direction, $\varepsilon$ is the extinction coefficient, 1 is the path length of the cell in the excitation and emission direction, and $\mathrm{C}$ is the ligand concentration. The corrected quenching fluorescence titration curves were inverted and fitted to the saturation curve equation by means of nonlinear least-squares regression analysis.

$$
F_{\text {oorm }}=\frac{F_{\max }\left[L_{f}\right]}{K_{d}+\left[L_{f}\right]}
$$

$F_{\max }$ is the plateau fluorescence value. Concentrations (bound $\left[\mathrm{L}_{b}\right]$ and free $\left[\mathrm{L}_{\mathrm{f}}\right]$ ligand) and $\mathrm{K}_{\mathrm{d}}$ the stoichiometric dissociation binding constants were calculated using the following equation:

$$
\left[L_{\xi_{2}}\right]=\frac{1}{2}\left\{\left(\left[L_{Q}\right]+\left[P_{Q}\right]+K_{\phi}\right)-\left(\left[\left[L_{Q}\right]+\left[F_{Q}\right]+K_{\phi}\right)^{2}-4\left[P_{Q}\right]\left[L_{Q}\right]\right)^{1 / 2}\right\}
$$


in which $\left[\mathrm{L}_{0}\right]$ and $\left[\mathrm{P}_{0}\right]$ are the total ligand and protein concentrations. The algorithm starts with an arbitrary opening $\mathrm{K}_{d}$ value. With this value, $\left[\mathrm{L}_{b}\right]$ and $\left[\mathrm{L}_{\mathrm{f}}\right]$ are calculated and then the nonlinear leastsquares regression analysis is executed. The initial set is corrected in the next step by a Newton-Gauss procedure. This iterative procedure is continued until the minimum sum of squared deviations between experimental and calculated values of $\mathrm{F}_{\text {corr }}$ is reached.

Fluorescence time course of binding of AMM4 and colchicine are monitored in a fluorescence spectrophotometer Horiba Jobin Yvon Fluoromax-3 at $25^{\circ} \mathrm{C}$ using $0.2 \mathrm{~cm}$ (excitation direction) $\mathrm{x} 1 \mathrm{~cm}$ cells (Hellma) thermostated at $25^{\circ} \mathrm{C}$. Emission fluorescence intensities were collected at $443 \mathrm{~nm}$ using an excitation wavelength of $350 \mathrm{~nm}$ and with emission and excitation slit widths of $5 \mathrm{~nm}$.

The concentrations of compounds were detected spectrophotometrically with a Beckman DU 7400 . The extinction coefficients $(\varepsilon)$ were determined by means of dissolving the compounds in DMSO and diluting this solution in $20 \mathrm{mM} \mathrm{NaPi}$ buffer at $\mathrm{pH} 7$, followed by measurement of the UV visible spectra. Three independent determinations allowed us to determine the value of the extinction coefficient at $354 \mathrm{~nm}$ (Table 5). The other values were calculated graphically.

\section{Table 5}

\begin{tabular}{clll} 
compound & & & \\
\hline $\mathbf{2}$ & $\varepsilon_{354 \mathrm{~nm}}=14100 \pm 2500$ & $\varepsilon_{295 \mathrm{~nm}}=3760$ & $\varepsilon_{330 \mathrm{~nm}}=9870$ \\
$\mathbf{3}$ & $\varepsilon_{354 \mathrm{~nm}}=12800 \pm 1700$ & $\varepsilon_{295 \mathrm{~nm}}=2844$ & $\varepsilon_{330 \mathrm{~nm}}=8533$ \\
$\mathbf{4}$ & $\varepsilon_{354 \mathrm{~nm}}=9100 \pm 2500$ & $\varepsilon_{295 \mathrm{~nm}}=2395$ & $\varepsilon_{330 \mathrm{~nm}}=6705$ \\
$\mathbf{5}$ & $\varepsilon_{354 \mathrm{~nm}}=10300 \pm 1400$ & $\varepsilon_{295 \mathrm{~nm}}=3679$ & $\varepsilon_{330 \mathrm{~nm}}=6621$ \\
$\mathbf{6}$ & $\varepsilon_{354 \mathrm{~nm}}=9300 \pm 1500$ & $\varepsilon_{295 \mathrm{~nm}}=3100$ & $\varepsilon_{330 \mathrm{~nm}}=5580$
\end{tabular}

\subsubsection{Molecular docking}

Molecular docking was performed using Autodock 4.2 [24]. The crystal structure of $\alpha \beta$ tubulin (PDB ID 1SA0) was used as a template. Nevertheless, the $\mathrm{C}$ and $\mathrm{D}$ subunits, stathmin, water molecules and bound ligands were previously removed from the protein structure in order to perform docking simulation. The GaussView 5.0 program [31] was used to build the structures of the colchicine derivatives 2-6. Local docking was made in such a way that the grid box covered the entire $\alpha \beta$-tubulin interface. The grid map was used with 126 points equally in each $\mathrm{x}, \mathrm{y}$ and $\mathrm{z}$ direction and with grid spacing $0.247 \AA$. The cluster was compared on the basis of the binding energy. The Lamarckian genetic algorithm was chosen to search for the best conformers. Molecular graphics were done with the 
program Visual Molecular Dynamics (VMD) [32]. LigPlot+ [33] has been used to show the interaction in 2-D between the compounds and the tubulin.

\section{Acknowledgments}

This research has been funded by the Ministerio de Economía y Competitividad (project CTQ201452949-P), by the Universitat Jaume I (project PI-1B2015-75) and by the Conselleria d'Educaciò, Investigaciò, Cultura i Sport de la Generalitat Valenciana (project PROMETEO 2013/027). A. M.-M. thanks the Conselleria d'Educaciò, Investigaciò, Cultura i Esport de la Generalitat Valenciana for financial support to a research stay in the laboratories in Marseille. The biological part has been supported by Inserm and the Université of Aix-Marseille.

\section{Supplementary Information}

Additional figures, graphics, experimental data, physical, IR, NMR and Mass spectrometry data of all new synthetic compounds are provided in the Supplementary Information.

\section{References}

[1] M. Aeluri, S. Chamakuri, B. Dasari, S. K. R. Guduru, R. Jimmidi, S. Jogula, P. Arya, Small molecule modulators of protein-protein interactions: selected case studies, Chem. Rev. 114 (2014) 4640-4694.

[2] J. Hong, Natural product synthesis at the interface of chemistry and biology, Chem. Eur. J. 20 (2014) 10204-10212.

[3] For a recent, interesting review, see: M. E. Maier, Design and synthesis of analogues of natural products, Org. Biomol. Chem. 13 (2015) 5302-5343.

[4] See, for example: C. Vilanova, S. Díaz-Oltra, J. Murga, E. Falomir, M. Carda, M. RedondoHorcajo, J. F. Díaz, I. Barasoain, J. A Marco, Design and synthesis of pironetin analogue/colchicine hybrids and study of their cytotoxic activity and mechanisms of interaction with tubulin, J. Med. Chem. 57 (2014) 10391-10403, and references to previous work cited therein.

[5] D. Hanahan, R. A. Weinberg, The hallmarks of cancer: the next generation, Cell 144 (201) 144 646-674.

[6] (a) L. Portt, G. Norman, C. Clapp, M. Greenwood, M. T. Greenwood, Anti-apoptosis and cell survival: a review, Biochim. Biophys. Acta 1813 (2011) 238-259. (b) F. Torres-Andón, B. Fadeel, 
Programmed cell death: molecular mechanisms and implications for safety assessment of nanomaterials, Acc. Chem. Res. 46 (2013) 733-742.

[7] (a) L. A. Amos, Microtubule structure and its stabilization, Org. Biomol. Chem. 2 (2004) $2153-$ 2160. (b) R. H. Wade, On and around microtubules: an overview, Mol. Biotechnol. 43 (2009) 177191. (c) A. Akhmanova, M. O. Steinmetz, Control of microtubule organization and dynamics: two ends in the limelight, Nat. Rev. Mol. Cell. Biol. 16 (2015) 711-726.

[8] (a) E. Nogales, H.-W. Wang, Structural intermediates in microtubule assembly and disassembly: how and why?, Curr. Opin. Cell Biol. 18 (2006) 179-184. (b) E. Nogales, H.-W. Wang, Structural mechanisms underlying nucleotide-dependent self-assembly of tubulin and its relatives. Curr. Opin. Struct. Biol. 16 (2006) 221-229. (c) G. M. Alushin, G. C. Lander, E. H. Kellogg, R. Zhang, D. Baker, E. Nogales, High-resolution microtubule structures reveal the structural transitions in $\alpha \beta$-tubulin upon GTP tydrolysis, Cell 157 (2014) 1117-1129.

[9] (a) T. Beckers, S. Mahboobi, Natural, semisynthetic and synthetic microtubule inhibitors for cancer therapy, Drugs Fut. 28 (20039 767-785. (b) J. A. Hadfield, S. Ducki, N. Hirst, A. T. McGown, Tubulin and microtubules as targets for anticancer drugs, Progr. Cell Cycle Res. 5 (2003) 309-325. (c) M. A. Jordan, L. Wilson, Microtubules as a target for anticancer drugs, Nat. Rev. Cancer, 4 (2004) 253-265. (d) E. Pasquier, M. Kavallaris, Microtubules: a dynamic target in cancer therapy, IUBMB Life 60 (2008) 165-170. (e) P. G. Morris, M. N. Fornier, Microtubule active agents: beyond the taxane frontier, Clin. Cancer Res. 14 (2008) 7167-7172. (f) E. A. Perez, Microtubule inhibitors: differentiating tubulin-inhibiting agents based on mechanisms of action, clinical activity, and resistance, Mol. Cancer Ther. 8 (2009) 2086-2095. (g) S. M. Chen, L.-H.Meng, J. Ding, New microtubule-inhibiting anticancer agents, Expert Opin. Invest. Drugs 19 (2010) 329-343. (h) D. Calligaris, P. Verdier-Pinard, F. Devred, C. Villard, D. Braguer, D. Lafitte, Microtubule targeting agents: from biophysics to proteomics, Cell. Mol. Life Sci. 67 (2010) 1089-1104. (i) R. Kaur, G. Kaur, R. K. Gill, R. Soni, J. Bariwal, Recent developments in tubulin polymerization inhibitors: an overview, Eur. J. Med. Chem. 87 (2014) 89-124.

[10] (a) K.-H. Altmann, J. Gertsch, Anticancer drugs from nature-natural products as a unique source of new microtubule-stabilizing agents, Nat. Prod. Rep. 24 (2007) 327-357. (b) D. G. I. Kingston, A natural love of natural products, J. Org. Chem. 73 (2008) 3975-3984. (c) D. G. I. Kingston, Tubulin-interactive natural products as anticancer agents, J. Nat. Prod. 72 (2009) 507515. (d) F. A. L. M. Eskens, P. Tresca, D. Tosi, L. Van Doorn, H. Fontaine, A. Van der Gaast, C. Veyrat-Follet, C. Oprea, M. Hospitel, V. Dieras, A phase I pharmacokinetic study of the vascular 
disrupting agent ombrabulin (AVE8062) and docetaxel in advanced solid tumours, Brit. J. Cancer 110 (2014), 2170-2177.

[11] (a) F. Roubille, E. Kritikou, D. Busseuil, S. Barrere-Lemaire, J.-C. Tardif, Colchicine: an old wine in a new bottle? Anti-Inflammatory \& Anti-Allergy Agents in Medicinal Chemistry 12 (2013) 14-23. (b) S. Sapra, Y. Bhalla, Nandani S. Sharma, G. Singh, K. Nepali, A. Budhiraja, K. L. Dhar, Colchicine and its various physicochemical and biological aspects, Med. Chem. Res. 22 (2013) 531-547. (c) S. Padeh, Y. Berkun. Familial Mediterranean fever. Curr. Opin. Rheumatol. 28 (2016) 523-529.

[12] C. Vilanova, S. Díaz-Oltra, J. Murga, E. Falomir, M. Carda, J. A. Marco, Inhibitory effect of pironetin analogue/colchicine hybrids on the expression of the VEGF, hTERT and c-Myc genes, Bioorg. Med. Chem. Lett. 25 (2015) 3194-3198.

[13] (a) V. M. Sánchez-Pedregal, C. Griesinger, The tubulin binding mode of MT stabilizing and destabilizing agents studied by NMR, Top. Curr. Chem. 286 (2009) 151-208. (b) B. Gigant, A. Cormier, A. Dorléans, R. B. G. Ravelli, M. Knossow, Microtubule-destabilizing agents: structural and mechanistic insights from the interaction of colchicine and vinblastine with tubulin, Top. Curr. Chem. 286 (2009) 259-278. (c) M. Botta, S. Forli, A. Magnani, F. Manetti, Molecular modeling approaches to study the binding mode on tubulin of microtubule destabilizing and stabilizing agents, Top. Curr. Chem. 286 (2009) 279-328. (d) G. Borisy, R. Heald, J. Howard, C. Janke, A. Musacchio, E. Nogales, Microtubules: 50 years on from the discovery of tubulin, Nat. Rev. Mol. Cell Biol. 17 (2016) 322-328.

[14] J. D. Bagnato, A. L. Eilers, R. A. Horton, C. B Grissom, Synthesis and characterization of a cobalamin-colchicine conjugate as a novel tumor-targeted cytotoxin, J. Org. Chem. 69 (2004) 8987-8996.

[15] (a) Compounds 1 and $\mathbf{2}$ were first mentioned without a detailed description of their physical properties in: H. Lettré, Zur Chemie und Biologie der Mitosegifte, Angew. Chem. 63 (1951) 421 430. (b) Compound 1 was again mentioned in: M. Černoch, J. Malinský, O. Tělupilová, F. Šantavý, Biologische Wirksamkeit der Colchicinderivate in Bezug auf ihre Konstitution, Arch. Int. Pharmacodyn. Ther. 99 (1954) 141-162. (c) For some biological activities of 1, see: A. Brossi, P. N. Sharma, L. Atwell, A. E. Jacobson, M. A. Iorio, M. Molinari, C. F. Chignells, Biological effects of modified colchicines. 2. Evaluation of catecholic colchicines, colchifolines, colchicide and novel N-acyl- and N-aroyldeacetylcolchicines, J. Med. Chem. 26 (1983) 1365 1369. To our knowledge compounds 3-10 have never been reported in the literature. 
[16] T. David-Pfeuty, C. Simon, D. Pantaloni, Effect of antimitotic drugs on tubulin GTPase activity and self assembly, J. Biol. Chem. 254 (1979) 11696-11702.

[17] (a) D. Saltarelli, D. Pantaloni, Polymerization of tubulin-colchicine complex and guanosine 5'triphosphate hydrolysis, Biochemistry 21 (1982) 2996-3006. (b) J. M. Andreu, T. Wagenknecht, S. N. Timasheff, Polymerization of the tubulin-colchicine complex: relation to microtubule assembly, Biochemistry 22 (1983)1556-1566.

[18] J. M. Andreu, S. N. Timasheff, Tubulin bound to colchicine forms polymers different from microtubules, Proc. Natl. Acad. Sci. U.S.A. 79 (1982) 6753-6756.

[19] P. Barbier, V. Peyrot, D. Leynadier, J. M. Andreu, The active GTP- and ground CDP-liganded states of tubulin are distinguished by the binding of chiral isomers of ethyl 5-amino-2-methyl1,2-dihydro-3-phenylpyrido[3,4-b]pyrazin-7-yl carbamate, Biochemistry 37 (1998) 758-768.

[20] J. M. Andreu, S. N. Timasheff, Conformational states of tubulin liganded to colchicine, tropolone methyl ether, and podophyllotoxin, Biochemistry 21 (1982) 6465-6476.

[21] (a) B. Bhattacharyya, J. Wolff, Promotion of fluorescence upon binding of colchicine to tubulin, Proc. Natl. Acad. Sci. U.S.A. 71 (1974) 2627-2631. (b) J. F. Diaz, J. M. Andreu, Kinetics of dissociation of the tubulin-colchicine complex. Complete reaction scheme and comparison to thermodynamic measurements, J. Biol. Chem. 266 (1991) 2890-2896. (c) A. Banerjee, R. F. Luduena, Kinetics of colchicine binding to purified $\beta$-tubulin isotypes from bovine brain, J. Biol. Chem. 267 (1992) 13335-13339.

[22] J. M. Andreu, M. J. Gorbunopff, J. C. Lee, S. N. Timasheff, Interaction of tubulin with bifunctional colchicine analogues: An equilibrium study, Biochemistry 23 (1984) 1742-1752.

[23] X. Zhang, Y. Kong, J. Zhang, M. Su, Y. Zhou, Y. Zang, J. Li, Y. Chen, Y. Fang, X. Zhang, W. $\mathrm{Lu}$, Design, synthesis and biological evaluation of colchicine derivatives as novel tubulin and histone deacetylase dual inhibitors, Eur. J. Med. Chem. 95 (2015) 127-135.

[24] G. M. Morris, R. Huey, W. Lindstrom, M. F. Sanner, R. K. Belew, D. S. Goodsell, A. J. Olson, AutoDock4 and AutoDockTools4: Automated Docking with Selective Receptor Flexibility, J. Comput Chem. 30 (2009) 2785-2791.

[25] (a) N. Zonta, I. J. Grimstead, N. J. Avis, A. Brancale, Accessible haptic technology for drug design applications, J. Mol. Model. 15 (2009) 193-196. (b) A. Gangjee, Y. Zhao, L. Lin, S. Raghavan, E. G. Roberts, A. L. Risinger, E. Hamel, S. L. Mooberry, Synthesis and discovery of water-soluble microtubule targeting agents that bind to the colchicine site on tubulin and circumvent Pgp mediated resistance, J. Med. Chem. 53 (2010) 8116-8128. (c) A. Rai, T. K. 
Gupta, S. Kini, A. Kunwar, A. Surolia, D. Panda, CXI-benzo-84 reversibly binds to tubulin at colchicine site and induces apoptosis in cancer cells, Biochem. Pharmacol. 86 (2013) 378-391.

[26] S. Rodríguez-Nieto, M. A. Medina, A. R. Quesada, A reevaluation of fumagillin selectivity towards endothelial cells, Anticancer Res. 21 (2001) 3457-3460.

[27] C. A. Schneider, W. S. Rasband, K. W. Eliceiri, NIH Image to ImageJ: 25 years of image analysis, Nat. Methods 9 (2012) 671-675.

[28] R. C. Weisenberg, G. G. Borisy, E. W. Taylor, Colchicine-binding protein of mammalian brain and its relation to microtubules, Biochemistry 7 (1968) 4466-4479.

[29] P. Barbier, C. Gregoire, F. Devred, M. Sarrazin, V. Peyrot, In vitro effect of cryptophycin 52 on microtubule assembly and tubulin: molecular modeling of the mechanism of action of a new antimitotic drug, Biochemistry 40 (2001) 13510-13519.

[30] J. R. Lakowicz, Principles of Fluorescence Spectroscopy, Plenum Press: New York, 1983, 1-496.

[31] R. Dennington, T. Keith, J. Millam, GaussView, Version 5, Semichem Inc., Shawnee Mission, KS, 2009.

[32] W. Humphrey, A. Dalke, K. Schulten, VMD: Visual Molecular Dynamics, J. Molec. Graphics Model. 14 (1996) 33-38.

[33] R. A. Laskowski, M. B. Swindells, LigPlot+: multiple ligand-protein interaction diagrams for drug discovery, J. Chem. Inf. Model. 51 (2011) 2778-2786. 